\title{
EARLY POSTNATAL DIFFERENTIATION OF MUSCLE FIBRES AND THE OCCURRENCE OF MYOFIBRILLAR HYPOPLASIA IN PIGLETS*
}

\author{
1) Z. LUKÁS, 2) LL. PIVNÍK, $\left.{ }^{2}\right)$ I. STRAKA, ${ }^{1}$ ) J. RAMPOCHOVÁ, ${ }^{1}$ ) L.ŠTĚPÁNOVÁ, \\ $\left.{ }^{2}\right)$ J. KAMAN, ${ }^{8}$ )J. VITOUCH \\ 1) II. Department of Pathology, Children's Hospital, 66263 Brno \\ 2) Department of Pathological Morphology and Parasitology, University of Veterinary Science, \\ 61242 Brno \\ 3) State Research Institute of Materials, 61700 Brno
}

Received April 15, 1981

\begin{abstract}
Lukáš Z., L. Pivník, I. Straka, J. Rampochová, L. Stěpánová, J. Kaman, J. Vitouch : Early Postnatal Differentiation of Muscle Fibres and the Occurrence of Myofibrillar Hypoplasia in Piglets. Acta vet. Brno, 51, 1982: 31-45

The type-representation of muscle fibres affected by myofibrillar hypoplasia and an assessment of the degree of histochemical differentiation of primary muscle bundles were carried out on $\mathrm{m}$. longissimus dorsi and $\mathrm{m}$. gracilis of piglets sufferring from splayleg syndrome and healthy 'piglets. Serial transverse sections with the detection of myosine Ca-ATPase with and without acid preincubation were used to establish the type of muscle fibres. It was found that myofibrillar hypoplasia (MFH) affects in our herds both piglets with splayleg syndrome and clinically healthy ones, including those form herds free from splayleg syndrome. No statistically significant differences were found in the proportion of the size of primary and secondary foetal fibres between the groups of animals studied. Histochemical differentiation of primary bundles in the two groups includes the same stages of development, but structures with more advanced differentiation occurred more often in clinically healthy animals, i. e. those with II.C-type fibres present and with more than one type I fibre in the centre of primary bundles. Myofibrillar hypoplasia affects II fibres preferentially, and where differentiation had occurred II.C fibres were not usually affected by MFH. Nor was MFH found in intrafusal fibres.
\end{abstract}

Splayleg syndrome, myofibrillar hypoplasia, muscle-fibre type differentiation, newborn piglets, histochemistry, histometry.

Many countries with advanced pig breeding pay attention to the splayleg syndrome in newborn pigs of some meat breeds. During the past ten years it has been a matter of intensive research of the veterinary and some other institutions in Czechoslovakia, because it caused severe damage to the intentions of the whole-state hybridization programme. According to the foreign (Ward 1978 and others) as well as inland (Va ř ejčko 1980) reports the genetic factors are of prime importance in the occurrence of the syndrome, even if one cannot overlook supposed influences of the environment such as housing, feeding, stress factors, etc.

This has been proved by the fact that substantial reduction of some lines of the breeds Landrace and Belgian Landrace (Beneš 1980; Vyvlečka 1980; Sedlák 1980 and Mesároš 1981) as well as using of some other breeds (Hampshire, Duroc) in the production of two- or three-breed hybrids caused a marked decrease of proportions of affected animals in the large-scale breeding. It is very important to take advantage of these information for the large-scale production of the pork meat.

* This investigation received financial support from WHO 
The actual cause of the defective motility of piglets as well as the relation of the reported alterations of skeletal muscles, above all the so-called myofibrillar hypoplasia (MFH), to the clinical state have yet to be explained. The MFH syndrome was originally found in the skeletal muscles of clinically affected piglets but a similar deficiency was found in clinically normal littermates (Thurley et al. 1967; Thurley and Done 1969). Later, the MFH has been repeatedly described in muscles of the unaffected animals (Cooper et al. 1979 do not describe but probably illustrate MFH in piglets from an intact breed, further Schlotke and Koch 1978, Zelená and Jirmanová 1978, Lukáš et al. 1978, Cox et al. 1979, Ward and Bradley 1980, Bradley et al. 1980). Only Hanzlíková (1980) found MFH in clinically affected piglets, but not in heal-thy in dividuals.

Many authors tried to establish the morphological background for both affected and unaffected animals in the following parameters: the presence or frequency of ultrastructural changes (B ergmann 1976, Zelená et al. 1978, Zelená and Jirmanová 1979; Ward and Bradley 1980; Bradley et al. 1980; Buček et al. 1982), the changes in the distribution of the cross-sectional area of the muscle fibres (Cox et al. 1979), or the differences in the stage of differentiation of the primary muscle bundles (Lukáš et al. 1978; Hanzlíková 1980). From the former point of view the results were so divergent that the opinion that the splayleg syndrome potentially comprises several distinct entities (Ward 1980) seems to be correct. The quantitative study of Cox et. al. (1979) brought the finding of a different distribution pattern in the CSA (cross section area) of the muscle fibres in the affected animals. And finally the results of the two last reports indicate some delay in the type differentiation of affected animals.

In the present paper fibre-type differentiation of the primary muscle bundles in both groups of newborn piglets is compared from the point of view of the suggested muscle fibre type transformation taking place at this stage of development (Lukáš et al. 1982). Further, involvement of the muscle fibre types in the $\mathrm{MFH}$ is studied.

\section{Materials and Methods}

M. longissimus dorsi and $\mathrm{m}$. gracilis were studied in newborn piglets of the Slovak Meat White and Czech Large White breeds and in cross-breeds of them with Landrace and Latvian White. Some of the piglets suffered from the splayleg syndrome others being unaffected. The healthy animals $9,10,11$ and 12 were from litters where no splayleg syndrome has yet been noticed (Tab. $1-4)$.

Muscle biopsies were performed under general ether anaesthesia immediately after the disappearance of the interdigital or jab reflex. Muscle samples were taken in a standard manner in all animals, from the left side of the body with animal lying on its side or abdomen. The samples were deep-frozen in propane-butane mixture cooled with liquid nitrogen; transverse cryostat sections were processed by a palette of methods which allow examination of the structure, determination of fibre type, assessment of the intensity of oxidative and glycolytic metabolism, distribution of glycogen and lipids as well as the motor-end plates (Lukáš and Dvořák 1977). Fibre type classification was performed on consecutive sections with histochemical reaction for Ca-ATPase with and without acid pre-incubation at $\mathrm{pH} 4.3$ (or 4.6) The arrangement of the primary muscle bundles was studied by determination of the numerical ratio of fibres I and II $\left(n_{1}: n_{2}\right)$ and also by occurrence of type IIC fibres in the bundles and by quantitative examination of the primary and secondary foetal fibres (PFF, SFF). Measurement of diameters of both fibre types was performed using objective and ocular micrometers or by direct measurement of the diameters in photomicrographs. In each biopsy at least 40 type I fibres or 50 type II fibres were measured. The results are not so exact as in semi-thick sections stained by alcian blue, but demonstration of Ca-ATPase in neonatal muscles is the only method which gives reliable fibre type differentiation. The values of diameters of both type I fibres $\left(D_{1}\right)$ and type II $\left(D_{2}\right)$ as well as the values $D_{1}: D_{2}$ were compared among the individual groups of animals, group A consisting of affected animals, group B of unaffected animals but from herds where splayleg syndrome occurs and group $C$ of unaffected animals where splayleg has not been reported yet. In addition to comparison of the individual groups (A vers. B vers. C) also associated groups were compared (A vers. B $+\mathbf{C}$ and $\mathbf{A}+\mathbf{B}$ vers. $\mathbf{C}$ ). Statistical evaluation of significance of the differences revealed was performed by the Scheffe method (1973). The extent of the myofibrillar deficiency was assessed as the percentage of the section area occupied by muscle fibres sufferring from myofibrillar hypoplasia (this assessment involves a risk of subjective error, so it was not evaluated statistically). 


\section{Results}

The results indicate that MFH is found in the muscles of pigs suffering from splayleg syndrome and healthy pigs alike, even if the latter are from herds where splayleg syndrome is not known to occur (Tables 1-4). The extent of the deficit in the two groups varies considerably. Since MFH appears to have an irregular, patchy distribution, the extent found certainly cannot be taken as an indication of the overall degree to which the muscle is affected.

Table 1

M. longissimus dorsi of unaffected animals

\begin{tabular}{|c|c|c|c|c|c|c|c|}
\hline$\underset{\text { Age }}{\text { Animal/ }}$ & $\begin{array}{c}\text { Ca-ATPase } \\
\text { differ. }\end{array}$ & $\begin{array}{l}\mathrm{D}_{1} \pm 8 \text { (coeff. var. \%) } \\
\mathrm{D}_{2} \pm 8 \text { (coeff. var. \%) }\end{array}$ & $D_{1} / D_{2}$ & $\mathrm{n}_{\mathbf{1}} /$ bundle & $\begin{array}{l}4,3+\mathrm{Ca}- \\
\text { ATPase }\end{array}$ & \multicolumn{2}{|c|}{$\% \quad \begin{array}{c}\text { Deficiency } \\
\% \quad \text { fibre type }\end{array}$} \\
\hline $1 / 28$ & $0-+$ & $\begin{array}{r}15.18 \pm 2.07(13.6) \\
8.48+2.28(26.9)\end{array}$ & 1.79 & 1.2 & $\mathbf{0}$ & $90-100$ & II \\
\hline $2 / 48$ & $0-+$ & $\begin{array}{r}14.66 \pm 1.86(12.7) \\
7.41\end{array}$ & 1.96 & 1.3 & $\mathbf{O}$ & 70 & II \\
\hline $3 / 36$ & $0-+$ & $\begin{array}{r}17.87 \pm 2.91(16.3) \\
7.89 \pm 2.06(26.1)\end{array}$ & 2.26 & 1.0 & $\mathbf{O}$ & 100 & II \\
\hline $4 / 44$ & ++ & $\begin{array}{r}16.61 \pm 2.13(12.7) \\
8.85 \pm 2.17(24.5)\end{array}$ & 1.88 & 1.2 & DIFF & 70 & IIA \\
\hline $5 / 44$ & ++ & $\begin{array}{r}18.40 \pm 1.80(9.8) \\
8.39\end{array}$ & 1.69 & 1.6 & DIFF & 80 & IIA \\
\hline $6 / 45$ & ++ & $\begin{array}{r}8.39 \pm 2.24(26.7) \\
17.83 \pm 2.43(13.6) \\
10.18 \pm 2.43(23.9)\end{array}$ & 1.75 & 1.1 & DIFF & $90-100$ & IIA \\
\hline $7 / 31$ & + & $\begin{array}{r}16.67 \pm 1.53(9.2) \\
8.38 \pm 2.12(25.3)\end{array}$ & 1.99 & 1.0 & SD & 80 & IIA \\
\hline $8 / 30$ & + & $\begin{array}{r}17.31 \pm 1.95(11.3) \\
6.73 \pm 2.11(31.3)\end{array}$ & 2.57 & 1.0 & INV & 60 & II \\
\hline$* 9 / 12$ & ++ & $\begin{array}{r}15.98 \pm 2.38(14.9) \\
7.87 \pm 1.91(24.3)\end{array}$ & 2.03 & 1.2 & DIFF & $70-80$ & IIA \\
\hline$* 10 / 12$ & ++ & $\begin{array}{r}13.25 \pm 1.96(14.8) \\
8.05 \pm 1.99(24.7)\end{array}$ & 1.65 & 1.0 & DIFF & 90 & IIA \\
\hline$* 11 / 27$ & ++ & $17.57 \pm 2.28(13.5)$ & 1.86 & 1.2 & - DIFF & 90 & IIA \\
\hline$* 12 / 28$ & ++ & $\begin{array}{r}9.44 \pm 2.44(25.8) \\
19.76 \pm 2.15(10.9) \\
11.07 \pm 2.46(22.2)\end{array}$ & 1.79 & 1.2 & DIFF & 20 & IIA \\
\hline
\end{tabular}

Table 2

M. gracilis of unaffected animals

\begin{tabular}{|c|c|c|c|c|c|c|c|}
\hline$\underset{\text { Age }}{\text { Animal/ }}$ & $\begin{array}{l}\text { Ca-ATPase } \\
\text { differ. }\end{array}$ & $\begin{array}{l}D_{1} \pm s \text { (coeff. var. } \% \text { ) } \\
D_{2} \pm \text { s (coeff. var. \%) }\end{array}$ & $D_{1} / D_{2}$ & $\mathrm{n}_{1} /$ bundle & $\begin{array}{l}4.3+\mathrm{Ca}- \\
\text { ATPase }\end{array}$ & \multicolumn{2}{|c|}{$\begin{array}{l}\text { Deficiency } \\
\text { fibre type }\end{array}$} \\
\hline $1 / 28$ & $0-+$ & $\begin{array}{r}11.55 \pm 1.73(14.9) \\
9.39 \pm 1.91(20.3)\end{array}$ & 1.23 & 1.6 & 0 & 50 & II \\
\hline $2 / 48$ & + & $\begin{array}{r}11.60 \pm 1.71(14.7) \\
8.68 \pm 2.41(27.7)\end{array}$ & 1.34 & 2.0 & $\mathbf{O}$ & 30 & II \\
\hline $3 / 36$ & ++ & $\begin{array}{r}11.45 \pm 1.68(14.6) \\
8.92 \pm 1.89(21.2)\end{array}$ & 1.28 & 1.1 & O. & 40 & II \\
\hline $4 / 44$ & ++ & $\begin{array}{r}15.47 \pm 1.80(11.6) \\
9.33\end{array}$ & 1.66 & 1.1 & DIFF & 30 & IIA \\
\hline $6 / 45$ & ++ & $\begin{array}{l}19.95 \pm 3.30(26.9) \\
10.64 \pm 2.29(21.5)\end{array}$ & 1.88 & 1.8 & DIFF & 50 & II \\
\hline $7 / 31$ & ++ & $\begin{array}{r}12.45 \pm 2.61(20.9) \\
9.39 \pm 1.86(19.8)\end{array}$ & 1.33 & 1.0 & INV & $40-50$ & II \\
\hline $8 / 30$ & + & $\begin{array}{r}12.68 \pm 1.68(13.2) \\
9.12 \pm 2.19(24.0)\end{array}$ & 1.39 & 1.0 & INV & $5-10$ & II \\
\hline$* 9 / 12$ & $0-+$ & $\begin{array}{r}11.40 \pm 2.32(20.3) \\
8.24 \pm 1.81(21.9)\end{array}$ & 1.38 & - & $\mathbf{0}$ & 80 & II \\
\hline${ }^{*} 10 / 12$ & + & $\begin{array}{r}12.90 \pm 1.60(12.4) \\
9.96+2.07(20.8)\end{array}$ & 1.17 & 1.0 & INV & 30 & II \\
\hline$* 11 / 27$ & ++ & $\begin{array}{r}10.86 \pm 1.49(13.7) \\
9.30\end{array}$ & 1.30 & 1.0 & DIFF & 10 & II \\
\hline$* 12 / 28$ & +-++ & $\begin{array}{l}12.66 \pm 1.57(12.4) \\
10.14 \pm 1.88(18.5)\end{array}$ & 1.25 & 1.2 & DIFF & $5-10$ & IIA \\
\hline
\end{tabular}


Table 3

M. Longissimus dorsi of splayleg syndrome-afiected animals

\begin{tabular}{|c|c|c|c|c|c|c|c|}
\hline$\underset{\text { Age }}{\text { Animal }}$ & $\begin{array}{l}\text { Ca-ATPase } \\
\text { differ. }\end{array}$ & $\begin{array}{l}D_{1} \pm 8 \text { (coeff. var. \%) } \\
D_{1} \pm \text { s (coeff. var. \%) }\end{array}$ & $\mathbf{D}_{1} / \mathbf{D}_{\mathbf{2}}$ & $n_{1} /$ bundle & $\begin{array}{l}4.3+\mathrm{Ca}- \\
\text { ATPase }\end{array}$ & \multicolumn{2}{|c|}{$\begin{array}{l}\text { Deficiency } \\
\text { fibre type }\end{array}$} \\
\hline $14 / 36$ & $\mathbf{0}-+$ & $12.68 \pm 1.78(14.0)$ & 1.38 & 1.3 & $\mathbf{0}$ & $90-100$ & II \\
\hline $15 / 36$ & $0-+$ & $\begin{array}{r}15.17 \pm 2.23(14.7) \\
7.69\end{array}$ & 1.97 & 1.1 & $\mathbf{0}$ & 80 & II \\
\hline $16 / 37$ & + & $11.86 \pm 2.10(17.7)$ & 1.61 & 1.0 & INV & 90 & II \\
\hline $17 / 37$ & + & $12.31 \pm 1.96(15.9)$ & 1.31 & 1.0 & DIFF & 20 & IIA \\
\hline $18 / 18$ & + & $18.21 \pm 2.54(13.9)$ & 1.97 & 1.0 & $\mathbf{O}$ & 100 & II \\
\hline $19 / 18$ & + & $17.45 \pm 2.01(11.5)$ & 2.06 & 1.0 & $\mathbf{O}$ & 80 & II \\
\hline $20 / 11$ & ++ & $\begin{array}{r}14.98 \pm 2.20(14.7) \\
7.79 \pm 1.82(23.4)\end{array}$ & 1.92 & 1.0 & DIFF & $90-100$ & IIA \\
\hline $21 / 11$ & ++ & $\begin{array}{r}14.92 \pm 1.72(11.5) \\
6.9 \pm 1.74(25.2)\end{array}$ & 2.16 & 1.0 & DIFF & $90-100$ & IIA \\
\hline $22 / 11$ & ++ & $\begin{array}{r}16.71 \pm 2.33(13.9) \\
7.01 \pm 1.60(22.8)\end{array}$ & 2.38 & 1.1 & SD & 100 & IIA \\
\hline
\end{tabular}

Table 4

M. gracilis of splayleg syndrome-affected animals

\begin{tabular}{|c|c|c|c|c|c|c|c|}
\hline$\underset{\text { Age }}{\text { Animal/ }}$ & $\begin{array}{c}\text { Ca-ATPase } \\
\text { differ. }\end{array}$ & $\begin{array}{l}D_{1} \pm 8 \text { (coeff. var. \%) } \\
D_{2} \pm 8 \text { (coeff. var. } \% \text { ) }\end{array}$ & $\mathrm{D}_{1} / \mathrm{D}_{\mathbf{2}}$ & $\mathrm{n}_{1} /$ bundle & $\begin{array}{l}4.3+\mathrm{Ca-} \\
\text { ATPase }\end{array}$ & $\%$ & $\begin{array}{l}\text { Deficiency } \\
\text { fibre type }\end{array}$ \\
\hline $13 / 36$ & + & $\begin{array}{r}10.50 \pm 1.72(16.4) \\
9.20 \pm 2.17(23.6)\end{array}$ & 1.14 & 1.2 & $\mathbf{O}$ & $\mathbf{0}$ & 0 \\
\hline $14 / 36$ & $0-+$ & $11.33 \pm 1.60(14.1)$ & 1.46 & 1.5 & $\mathbf{O}$ & 0 & 0 \\
\hline $16 / 37$ & $0-+$ & $\begin{array}{r}11.57 \pm 1.71(14.7) \\
8.66+2.17(25.0)\end{array}$ & 1.34 & .1 .1 & SD & 80 & II \\
\hline $17 / 37$ & + & $\begin{array}{l}9.37 \pm 1.68(17.9) \\
8.75+1.77(20.2)\end{array}$ & 1.07 & 1.1 & INV & $\mathbf{0}$ & $\mathbf{0}$ \\
\hline $18 / 18$ & + & $\begin{array}{r}11.46 \pm 2.40(20.9) \\
8.42\end{array}$ & 1.36 & 1.0 & INV & 0 & 0 \\
\hline $19 / 18$ & $0-+$ & $14.70 \pm 2.70(18.3)$ & 1.40 & 1.1 & $\mathbf{O}$ & $?$ & II \\
\hline $20 / 12$ & ++ & $\begin{array}{r}10.51 \pm 2.36(22.4) \\
10.72 \pm 2.30(21.4) \\
7.09+0.86(12.1)\end{array}$ & 1.51 & 1.3 & INV & 60 & II \\
\hline $21 / 12$ & ++ & $\begin{array}{r}10.98 \pm 1.63(14.8) \\
8.23+2.31(28.0)\end{array}$ & 1.33 & 1.1 & SD- & 60 & II \\
\hline $22 / 12$ & ++ & $\begin{array}{r}10.26 \pm 1.54(15.0) \\
9.49 \pm 1.76(18.5)\end{array}$ & 1.08 & 1.3 & DIFF & 60 & II \\
\hline
\end{tabular}

Explanation of Tables 1 to 4

Animal/age: the number and the age (hours) of the piglet. Ca-ATPase, differ.: the possibility of fibre type identification is graded as 0 (differentiation impossible), $0-+$ (differentiation only in part of the section), + (sufficient differences) and ++ (marked differences). $\mathrm{D}_{1}$ and $\mathrm{D}_{2}$ : diameters of types $I$ and II fibres, respectively, $s$ : standard deviation, $n_{1} / b$ bundle: average number of type I fibres per primary bundle. 4.3 + Ca-ATPase: the pattern of reaction after acid preincubation is evaluated as INV (simple inversion of the reaction intensity without accurrence of IIC fibres), SD (sporadic differentiation of the II fibres), DIFF (type I, IIA and IIC fibres present in each bundle). $O$ means that the reaction after acid preincubation was not carried out. Deficiency, $\%$ : subjective assessment of the percentage of the section area occupied by muscle fibres of piglets suffering from myofibrillar hypoplasia. * : piglets from herds free from splayleg syndrome.

The question of whether the development and differentiation of muscles (irrespective of myofibrillar hypoplasia) are the same or different in healthy and affected animals was studied by histochemical and quantitative methods. Quantitative histochemical investigation (Tabs. 1 and 3 for $\mathrm{m}$. longissimus, Tabs. 2 and 

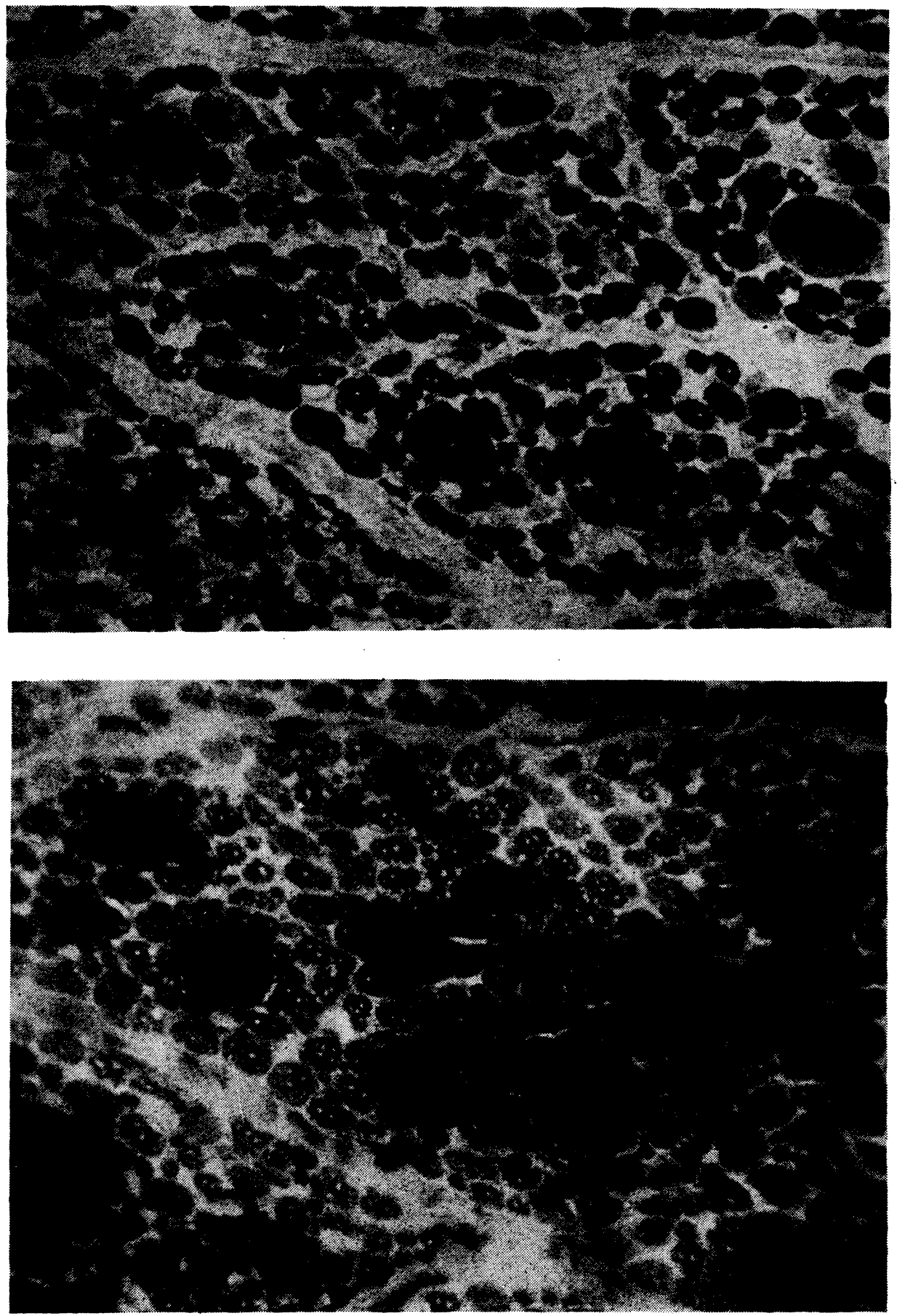

Fig. 1a, 1b*)

Large myotubes lying in the middle of the bundles exhibit a moderate reaction intensity; small fibres surrounding them react strongly (CaATPase, 1a). Simple inversion of the reaction after acid preincubation, sporadic IIC fibres marked by arrows (1b). Healthy animal. (x 600) 

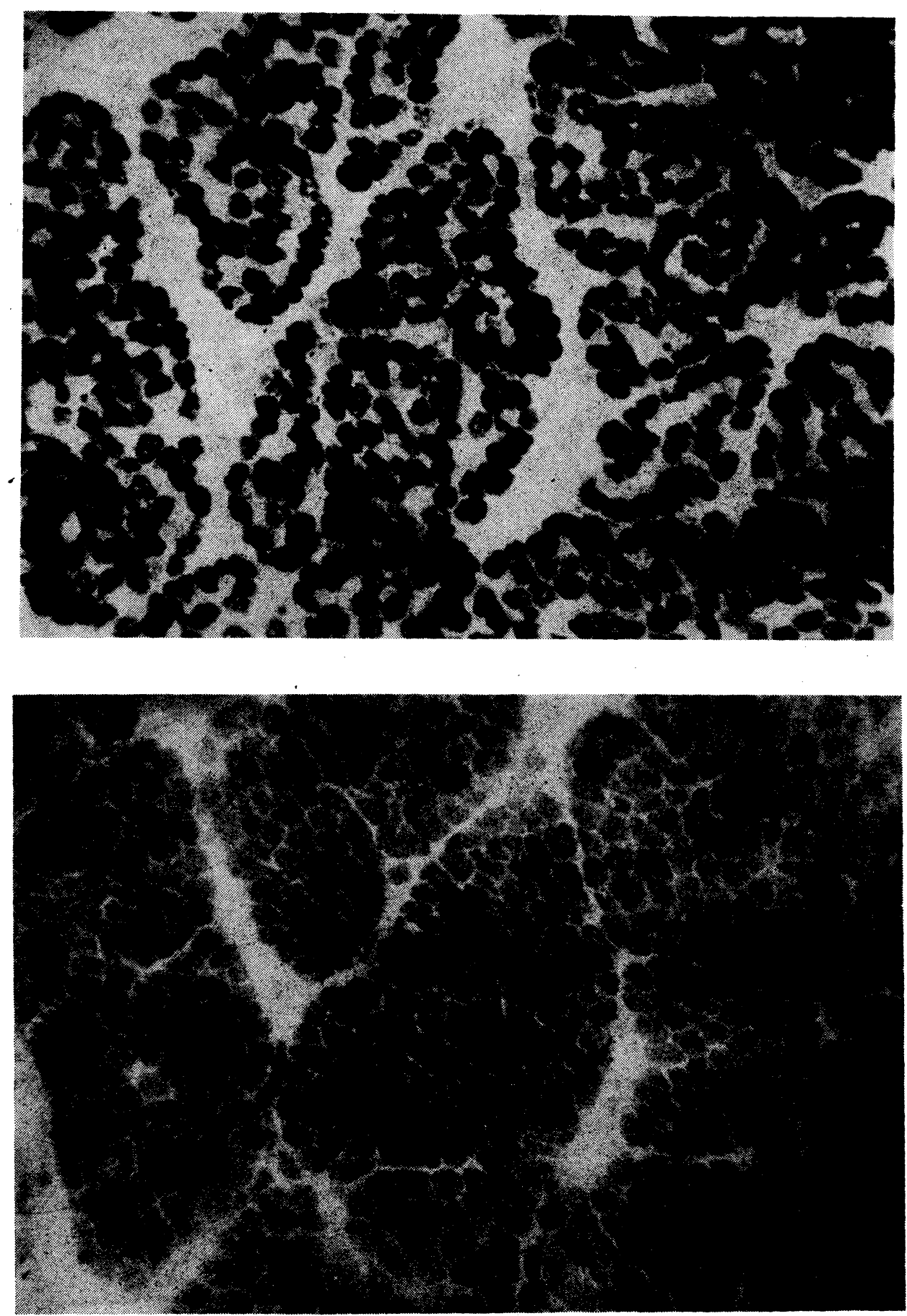

Fig. 2a, 2b *)

Inversion of the CaATPase reaction (2a) after acid preincubation (2b) as in the fig. 1 . Note less pronounced difference in the intensity of the reaction product between the two fibre types. Splay. leg. $(x 400)$ 

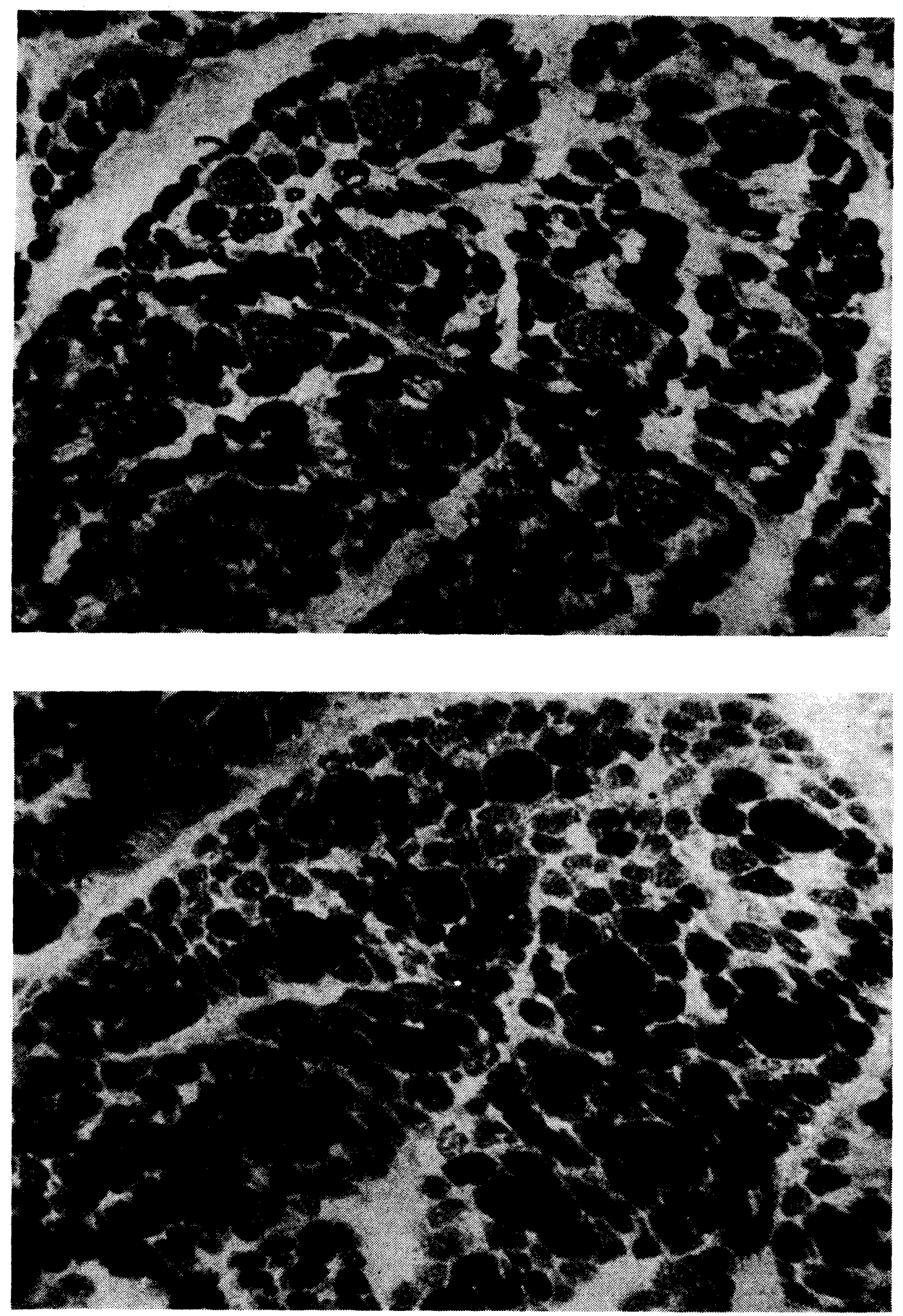

Fig. $3 a, 3 b *)$

Inversion of the ATPase reaction with differentiation of some type II. fibres. Type IIC fibres (alkali stable and acidostable) indicated by arrows. A bundle with two type I fibres (double arrows). Splayleg. (x 600) 

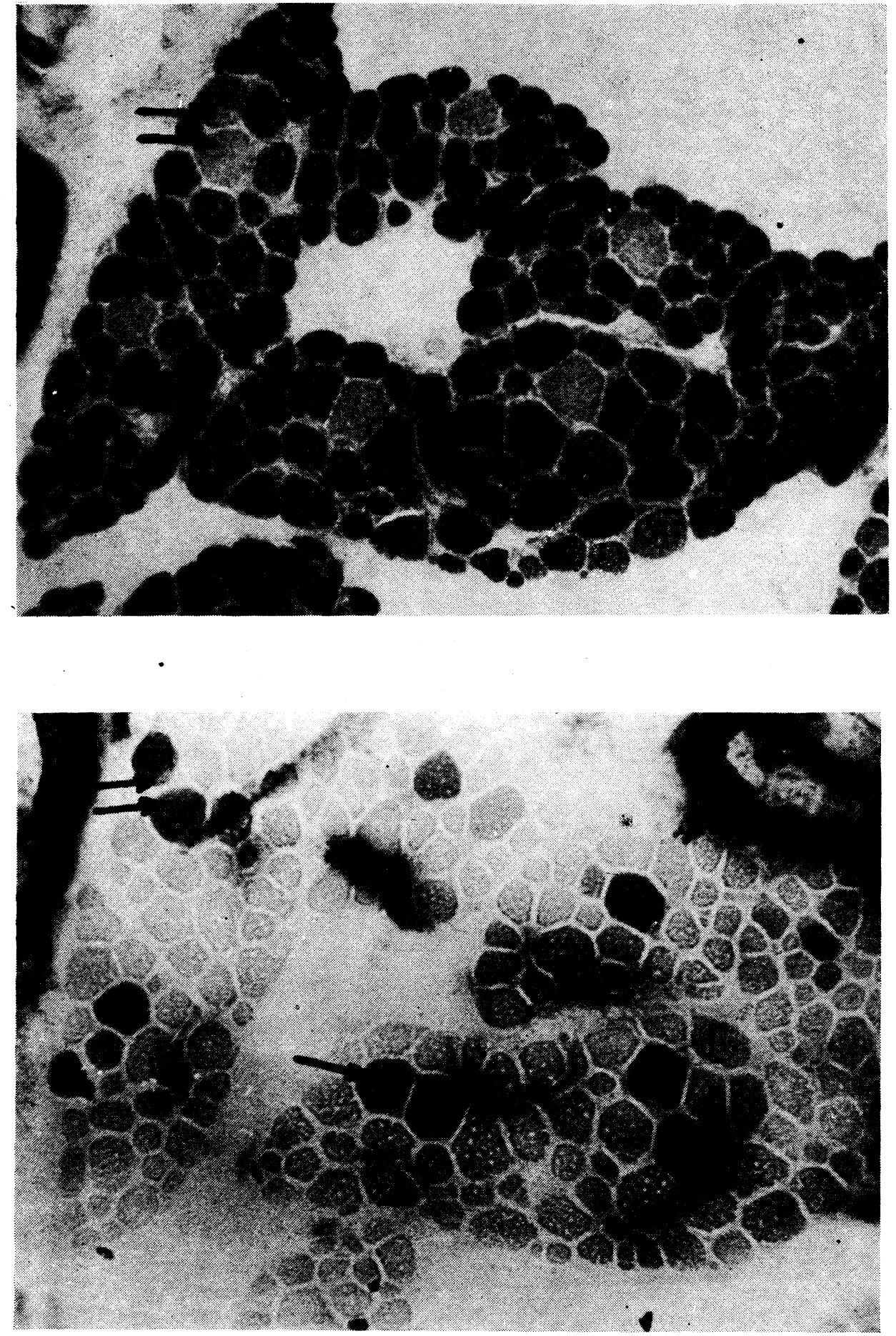
4 for $\mathrm{m}$. gracilis) showed a certain difference in $\mathrm{D}_{1}$ values between group $\mathrm{A}$ and the combined groups $\mathbf{B}+\mathbf{C}$ for $\mathrm{m}$. longissimus:

$$
\text { A vers. B + C . . . alpha }=5 \% \text { (95\% probability) }
$$

and in the values $D_{1}$ and $D_{2}$ between the same groups in m. gracilis:

$\mathrm{D}_{1}$ : A vers. $\mathrm{B}+\mathrm{C} \ldots \ldots$ alpha $=8 \%(92 \%$ probability $)$

$\mathrm{D}_{2}$ : A vers. B $+\mathrm{C} \ldots \ldots$ alpha $=8 \%(92 \%$ probability $)$

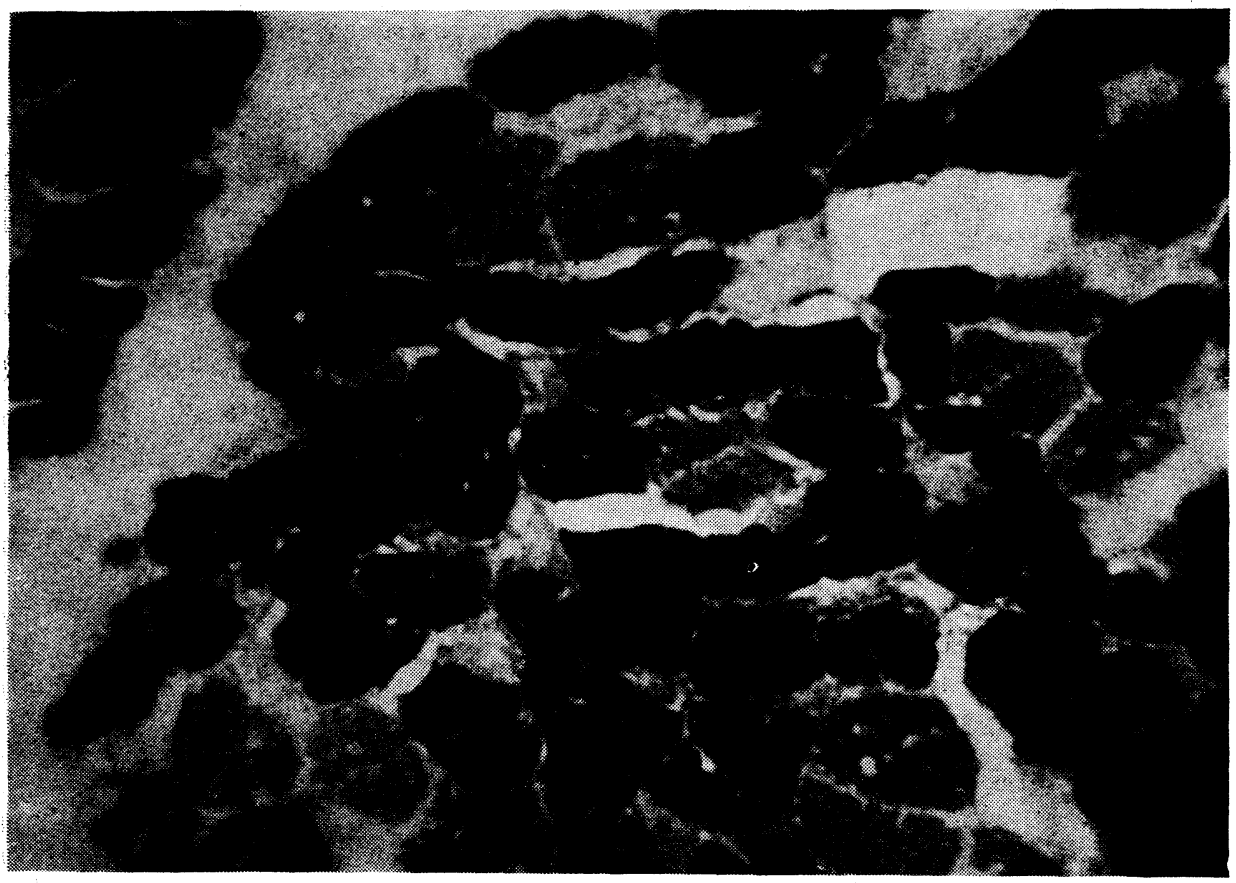

Fig. 5

Two central type I fibre. Splayleg. (x 800)

A comparison of all the other combinations given did reveal no statistically significant difference; this also applies to the values of the ratios of means $D_{1}: D_{2}$ both for $\mathrm{m}$. longissimus and $\mathrm{m}$. gracilis.

A comparison of variation coefficients for both types of fibres in both muscles of healthy and affected piglets shows that the corresponding values are much higher - up to twice as much - in II type fibres.

The results of Ca-ATPase reaction for primary muscle fibre bundles were as follows: the bundles with one light central type I fibre and the rest dark type II

\section{Fig. $4 a, 4 b *)$}

Inversion of CaTAPase reaction with differentiation of some II. type fibres. Type II C fibres indicated by arrows. One bundle with two central type I fibres (double arrows). Healthy animal.

*) consecutive sections 


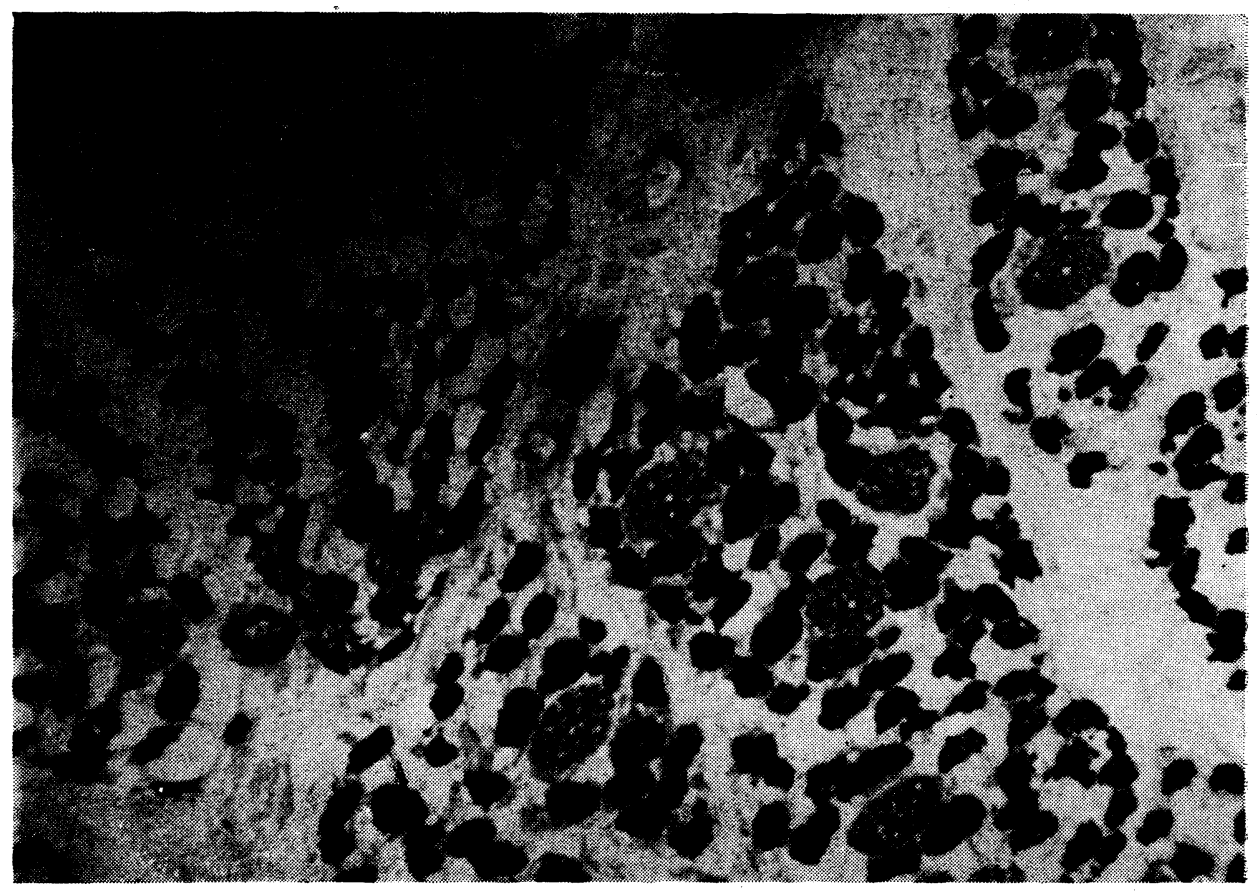

Fig. 6

Myofibrillar deficient type II fibres. Ca ATPase without preincubation. Healthy animal. (x 500)

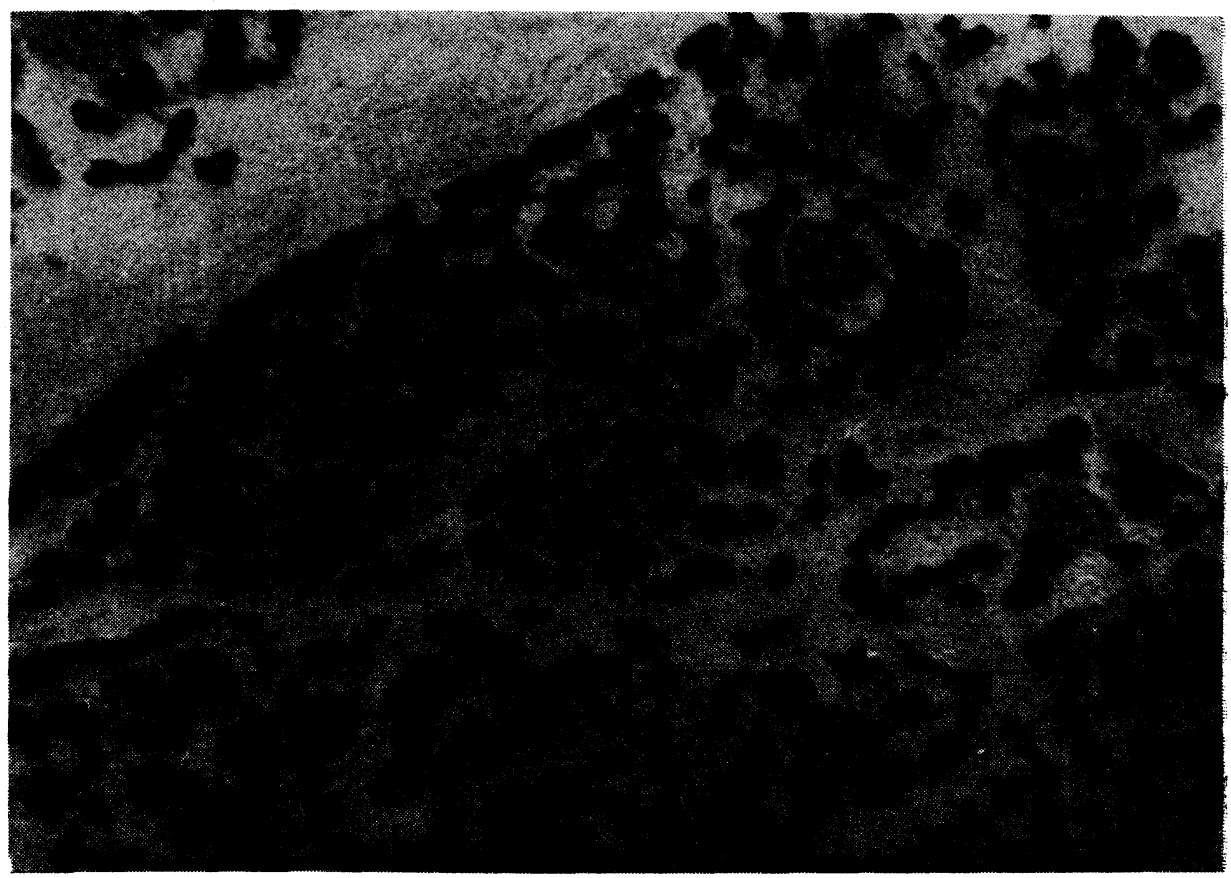




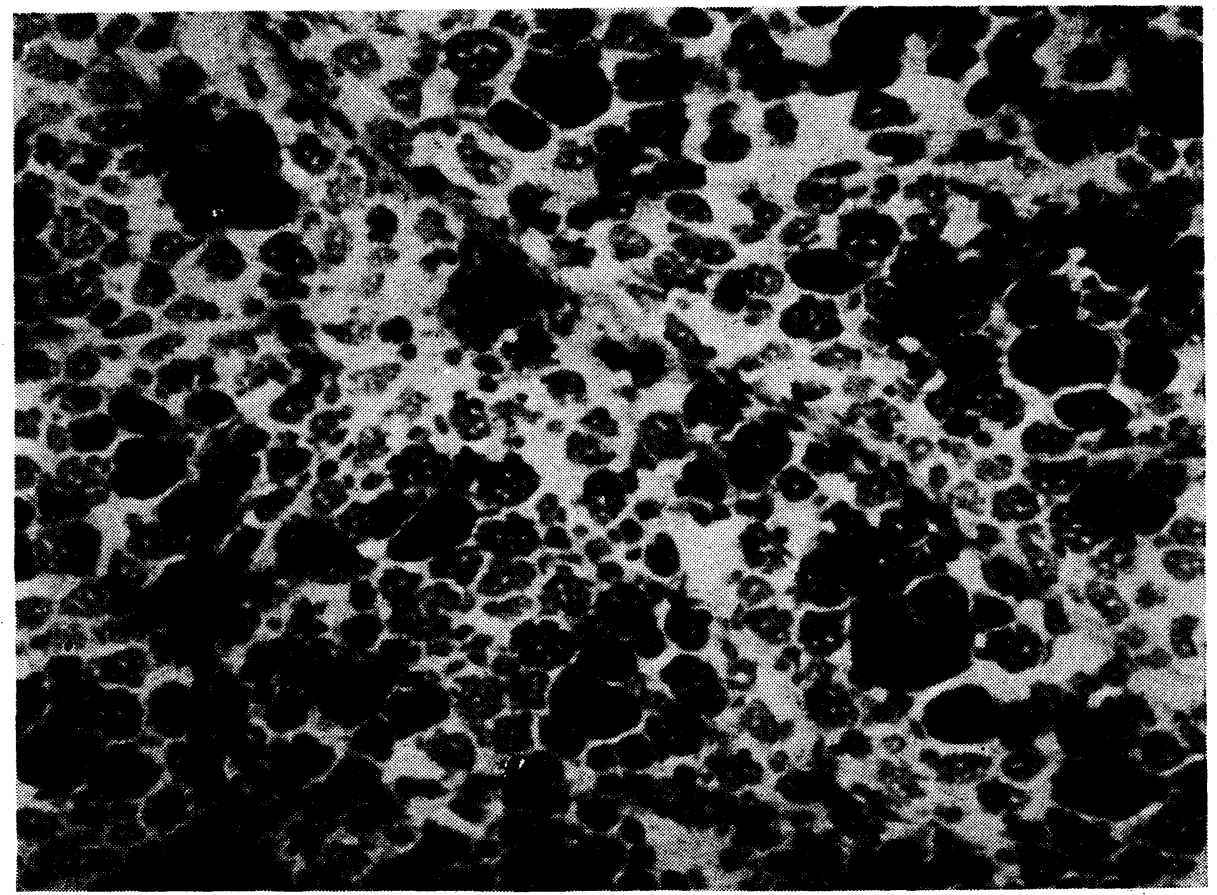

Fig. 8

Myofibrillar deficiency in type IIA fibres (weakly stained small fibres after acid preincubation). Type I and IIC fibres (darkly stained) without deficiency. Healthy animal. (x 400)

fibres (II.A) were repeatedly found in both healthy and splayleg-affected animals. Thus I fibres are alkali-labile, II. A fibres alkali-stable. Following preincubation there is a total inversion - I fibres are dark (acidostable), II. A fibres light (acidolabile). In affected animals the differences in reaction intensity were sometimes small and typing was difficult, as we have already reported elsewhere (Lukáš et al. 1978) (Figs. 1a, 1b, 2a, 2b).

Another type of primary bundle is that also containing II. C type fibres, which are both acido-stable and alkali-stable, and therefore react intensively both with and without preincubation. In the middle of these bundles there is again a I fibre, around this 1-3 II. C fibres, and the periphery is again formed by II. A fibres. This type of bundle was again found in both groups of animals (Figs. 3a, 3b, 4a, 4b).

Bundles with more than one central type I fibre or several more type II. C fibres surrounded by type II. A fibres were also found in both groups of animals (Figs. $3 a, 3 b, 4 a, 4 b \& 5$ ), but they were found far less often in affected animals than in healthy ones.

A further finding is the preferential affecting of the SFF with myofibrillar hypoplasia (Figs. $6 \& 7$ ) if the fibre type differentiation was pronounced. Type

Fig. 7

Myofibrillar deficiency in type II fibres. Ca ATPase without preincubation. Splayleg. (x 500) 
I fibres may also be affected in several muscles, but in most cases these were biopsies with some small freezing artifacts or where type differentiation was not clear.

In bundles in which type differentiation of type II fibres into II. A and II.C was clear, paracentral type II. C fibres, mostly clearly larger than the other type II fibres, were not usually afflicted with $\mathrm{MFH}$, in other words MFH was most pronounced on the periphery of the primary bundles, where there are the II. A fibres which have not undergone further differentiation (Fig. 8).

Myofibrillar hypoplasia has not as yet been found in intrafusal fibres either. Type preference in MFH, like the the fact of type I primary foetal fibres and intrafusal fibres not being affected, relates to both groups, piglets with splayleg sydrome and healthy ones.

\section{Discussion}

This work provides further evidence of the fact that MFH is found in our herds in both piglets with splayleg syndrome and clinically healthy ones, even in those from herds where splayleg syndrome has as yet not been known to occur. Thus a finding of MFH does not in itself indicate either the presence or the extent of splayleg syndrome.

There remains, however, the question of whether the muscles of affected piglets do not differ from those of healthy ones in other parameters. In our recent study (Lukáš et. al. 1982) we suggested a fall in the $D_{1} / D_{2}$ ratio as a criterion of gradual maturation of the secondary population of foetal fibres. In this respect the results of size comparison of the $D_{1} / D_{2}$ ratios between healthy and splayleg muscles are not significant, but it must be admitted that our populations were not large enough to allow definitive conclusions. In this respect it will be necessary to perform more extensive studies, such as that made by Cox et al. (1979) for the muscle fibres of newborn piglets without regard to type. They found that though the extent of MFH in healthy and affected piglets is approximately the same, there are differences in the size distribution of muscle fibres between the two groups.

A further criterion of the maturity of primary muscle bundles is derived from findings of type differentiation of their fibres. Our above-mentioned study describes a number of types of these bundles, probably corresponding to gradual maturation: the first type ( $\mathrm{F}$-foetal), where there are still considerable size differences between the centrally situated type I fibre and type II fibres. In the reaction to Ca-ATPase the first type is characterized by a light reaction product and the second by a dark one, and after acid preincubation there is a simple inversion of the reaction intensity. The second type ( $\mathrm{N}$-neonatal), where the reaction to Ca-ATPase without preincubation provides the same result, but after acid preincubation there is an intensive reaction not only of type I fibres but also of a further 1-3 fibres in their vicinity, which have therefore also acquired acidostability, and according to the nomenclature used (Dubowitz 1973) they are designated II. C. There are transitions between the two types. The third type (P-postnatal) is characterized by the presence of two (or more) centrally located type I fibres, in whose vicinity further type II. C fibres may occur. This type of primary bundle is closer to the mature condition, where there are on average 3.2 type I fibres (Davies 1972).

In our material all the basic types of primary bundles described occurred in both healthy and affected piglets. In this respect our findings differ from the data 
of Hanzlíková (1980), who described only type $F$ bundles in affected animals, while it follows from the photographs that type $\mathrm{N}$ or $\mathrm{P}$ were found in the healthy ones. The last two types are not distinguishable from either the description or the photographs since the results of ATPase reaction without acid preincubation are not given. Nonetheless in our material, too, structures of primary bundles were found more often in groups of healthy piglets, especially in $\mathrm{m}$. longissimus dorsi, these corresponding to a more advanced degree of differentiation, $i$. e. types $\mathrm{N}$ and $\mathrm{P}$. Thus histochemical (and therefore also perhaps functional) differentiation is probably really delayed in affected animals.

A further fact which has been ascertained is the preferential, perhaps selective, affecting of type II fibres, i. e. secondary foetal fibres with MFH.

Where differentiation of this type was found, i. e. the differentiation of paracentrally located II. C type fibres, these fibres did not display MFH. As far as the selective or preferential affecting of type II fibres with MFH is concerned, the published data do not agree in this respect. Only Lukáš et al. (1978) and Ward (1978a) referred to a higher susceptibility of II fibres to MFH. But there is also a description of the distribution of MFH in m. longissimus dorsi, which would correspond to such a situation, according to which the large central fibres of the bundles with the largest diameter and several adjacent fibres were regularly completely filled with myofibrils while the rest had MFH (Zelená and Jirmanová 1979). In intrafusal fibres no myofibrillar hypoplasia has as yet been found in any of the groups investigated, which is in accord with data published to date (Lukás et al. 1978, Ward and Bradley 1980). According to Swatland (1975) intrafusal fibres are more advanced in their differentiation that the extrafusal ones. Thus deficit states may perhaps occur preferentially in fibres which are histochemically and perhaps also functionally less differentiated. These are the fibres forming the majority in the primary bundles, and lying on their periphery. Most of them have no contact with the primary fibres and their possible inductive influence.

\section{Časná postnatální diferenciace svalových vláken a výskyt myofibrilární hypoplasie u selat}

Typová participace svalových vláken postižených deficitem myofibril (DMF) a stanovení stupně histochemické diferenciace primárních svalových snopcủ byla prováděna na $\mathrm{m}$. longissimus dorsi a $\mathrm{m}$. gracilis selat postižených syndromem svalové slabosti končetin (SSK) a selat zdravých. Př́čné sériové řezy s detekcí myozínové Ca-ATPázy po kyselé preinkubaci a bez ní sloužily $\mathrm{k}$ typovému zařazování svalových vláken. Bylo zjištěno, že DMF postihuje $v$ našich chovech jak selata postižená syndromem SSK, tak selata klinicky zdravá, včetně selat $\mathrm{z}$ chovů syndromu SSK prostých. Nebyly nalezeny statistické rozdíly ve velikosti primárních a sekundárních fetálních vláken mezi oběma skupinami zviřat. Histochemická diferenciace primárních snopečkủ u obou skupin zahrnuje táž vývojová stadia, avšak u klinicky zdravých zvírat se častěji vyskytly struktury s pokročilejši diferenciací, tedy $\mathrm{s}$ prítomností vláken II. $\mathrm{C}$ a $\mathrm{s}$ více než jedním vláknem I. v centru primárních svazečků. Myofibrilární hypoplasie postihuje preferenčně vlákna II., a tam, kde došlo $k$ jejich diferenciaci, nebyla postižena DMF zpravidla vlákna II. C. Rovněž v intrafuzálních vláknech nebyl DMF nalezen. 


\section{Ранная постнатальная дифференциация мышечных волокон и наличис миофибриллярной гипоплазии у поросят}

Типовая партиципация мыпечных волокон, пораженных дефицитом миофибрилл (ДМФ) и определение степени гистохимической дифференциации первичных мышечных пучков проводились на m. longissimus dorsi и m. gracilis поросят, пораженных синдромом мышечной слабости конечностей, и здоровых поросят. Поперечные серийные сечения с выявлением миозинной Са-аденосинтринфосфатазы после кислой преинкубации и без нее были предназначены для типовой классификации мышечных волокон. Было установлено, что в нашем свиноводстве наблъдается дефицит не только у поросят, пораженных синдромом мышечной слабости конечностей но и у поросят, где нет упомянутого синдрома, следовательно у поросят клинически здоровых. Не было выявлено статистической разницы величины первичных и вторичных утробных волокон между обеими группами животных. Гистохимическая дифференциация первичных пучков обеих групп вклъчает те же стадии развития, однако у клинически здоровых чаще наблъдались структуры с более развитой дифференциацией, следовательно с наличием волокон II.C и с более чем одним волоконом I. в центре первичных пучков. Миофибриллярная гипоплазия поражает прежде всего волокна II. в случае их дифференциации не были поражены рефицитом миофибрилл, как правило, волокна II.С. Дефицита миофибрилл в инфрафузальных волокнах не было также выявлено.

\section{References}

BENEŠ, S.: Personal communication 1980.

BERGMANN, V.: Elektronmikroskopische Befunde an der Skelettmuskulatur von neugeborenen Ferkeln mit Grätschstellung. Arch. exper. Vet. Med., 30, 1976: 239-260.

BRADLEY, R. - WARD, P. S. - BAILEY, J.: The ultrastructural morphology of the skeletal muscles of normal pigs and pigs with splayleg from birth to one week of age. J. Comp. Path., 90, 1980: 433-446.

BUCEK, J. - LUKÁ, Z. - PIVNfK, L.: Ultrastructural findings in neonatal piglets suffering from splayleg syndrome. Acta vet. Brno, 1982 (in press).

COOPER, C. C. - CASSENS, R. G. - KASTENSCHMIDT, L. L. - BRISKEY, E. J.: Histochemical characterisation of muscle differentiation. Develop. Biol., 23, 1970: 169-184.

COX, C. S. - WARD, P. S. - BASKERVILLE, A.: Quantitative image analysis of skeletal muscle from newborn pigs with myofibrillar hypoplasia and splayleg. Br. vet. J., 135, 1979: $370-376$.

DAVIES, A. S.: Postnatal changes in the histochemical fiber types of porcine skeletal muscle. J. Anat. Lond., 113, 1972: 213-240.

DUBOWITZ, V. - BROOKE, M.: Muscle biopsy: a modern approach (Major problems in neurology II.). Saunders and Co., 1973.

HANZLfKOVA, V.: Histochemical patterns in normal and splaylegged piglet muscle fibres. Histochemistry, 67, 1980: 311-319.

LUKÁS, Z. - DVORÁK, K.: Histochemical and quantitative methods in bioptic examination of skeletal muscles. Cs. patologie, 13, 1977: 21-23, (in Czech).

LUKÁS, Z. - KAMAN, J. - PIVNfK, L. Histochemical characteristics of the splayleg syndrome in newborn piglets. Acta vet. Brno, 47, 1978: 51-66.

LUKÁS̆, Z. - PIVNIK, L. - STRAKA, I. - RAMPOCHOVÁ, J. - ŠTĚPÁNOVÁ, L. KAMAN, J.: Morphological and histochemical type differentiation of the primary and secondary fetal muscle fibres in neonatal piglets. Zbl. Vet. Med. A, 29, 1982 in press.

MAJERCIAK, P. - POLLARSKY, J. - GRÁCIK, P. - HETÉNYI, L.: Recent results and further trends in pig breeding in Slovakia. Proceedings from the Conference on Pig Breeding. Dunajská Streda, CSSR, 1980 (in Czech).

MÉSÁROS, E.: Personal communication 1981. 
RADHAKRISHNA RAO, C.: Linear statistical inference and its applications. John Willey \& Sons USA, 1973.

REHAK, A.: Personal communication 1980.

SEDLAK, M.: Occurrence of the splayleg syndrome in piglets from the state farm Velké Albrechtice in line groups of sows and boars in years 1977-1979 (in Czech).

SWATLAND, H. J.: Histochemical development of myofibres in neonatal piglets. Res. Vet. Sci., 18, 1975: 253-257.

THURLEY, D. C. - GILBERT, F. R. - DONE, J. T.: Congenital splayleg of piglets myofibrillar hypoplasia. Vet. Rec., 80, 1967: 302-304.

THURLEY, D. C. - DONE, J. T.: The histology of myofibrillar hypoplasia of newborn pigs. Zbl. Vet. Med. A, 16, 1969: 732-740.

VAREJCKO, J.: Research on some hereditary disturbances of skeletal muscles in pigs. Research Report, University of Veterinary Science, Brno, 1980 (in Czech).

VYVLECKKA, J.: Personal communication 1980.

WARD, P. S.: Current state of knowledge on splayleg syndrome in newborn pigs and on other afflictions of the pig muscles. Lecture Univ. Brno, 7. 9. 1978 (a).

WARD, P. S.: The splayleg syndrome in newborn pigs: a review. The Veterinary Bulletin, 48, 1978 (b): $279-295$.

WARD, P. S. - BRADLEY, R.: The light microscopical morphology of the skeletal muscles of normal pigs and pigs with splayleg from birth to one week of age. J. Comp. Pathol., 90, 1980: $421-431$.

ZELENÁ, J. - JIRMANOVA, J.: Degenerative changes in skeletal muscles of piglets with congenital myofibrillar hypoplasia. Zbl. Vet. Med. A, 26, 1979: 652-665.

ZELENÁ, J. - SMETANA, K. - JIRMANOVA, J.: Abnormalities of the nuclear envelope in porcine muscle affected with congenital myofibrillar hypoplasia. Wirchow Arch., B, 28, 1978: $157-165$. 